\title{
PENGARUH INOKULASI CAMPURAN ISOLAT BAKTERI PELARUT FOSFAT INDIGENUS RIAU TERHADAP PERTUMBUHAN DAN PRODUKSI TANAMAN KEDELAI (Glycine max L. Merr)
}

\author{
(Effect of Riau Indigenus Phosphate Solubilizing Bacteria Isolate Mixture Inoculation \\ on Soybean Growth and Yield) \\ LUFITA NUR ALFIAH ${ }^{1}$, DELITA ZUL ${ }^{2}$, NELVIA ${ }^{2}$
${ }^{1}$ Program Studi Agroteknologi, Fakultas Pertanian, Universitas Pasir Pengaraian, Rokan Hulu, Riau Indonesia, Jln. Tuanku Tambusai, Kec.Rambah Hilir Kab. Rokan Hulu, Riau Indonesia
Telp. 081268187108 email: lufitanuralfiah@gmail.com
${ }^{2}$ Program Pasca Sarjana, Fakultas Pertanian, Universitas Riau, Pekanbaru, Riau
Kampus Bina Widya Km. 12,5 Jln. H.R. Subrantas, Panam, Pekanbaru, Riau

\begin{abstract}
At this time the oportunity increasing soybean production still open through optimize the fulfill of the nutrient of plants. Phosphorus is one of element nutrient essentiality macro those as very important to growth and development of plants. The existence it in land abundance, but the concentration $P$ who are get reserve by plant is very low. At acid land $P$ bunching aluminum $(A l)$ and iron ( $F e)$ meanwhile in land Alkhalin $P$ bounded calsium (Ca). The increasing efesiency of supply fosfat at plant can effort with exploit microorganism soluble phosphate group. Test potential solubility $P$ by BPF isolated from peat soil Biosphere Reserve Giam Siak Kecil Bukit Batu, Riau. Test was conducted and taken in semiquantitative which able to dissolve Ca3 (PO4) 2, FePo4 and phosphate rock. However adaptability and potential dilution BPF origin peat soils of Riau indigenus inoculated soybean in mineral soil until now unknown. This research was conducted in order to determine the effect of inoculation BPF indigenus Riau toward growth and yield of soybean. The study was conducted in factorial experiment using completely randomized design (RAL Factorial), as the first factor is soil treatment consisting of two levels ie: T0: soil without sterilization, T1: sterilized soil. The second factor is the provision isolates $B P F$ which consists of 4 levels, namely: B0: without inoculation, B1: 2 isolates BPF (BB_UB6 and $\left.B B \_K 9\right), B 2: 3$ isolates BPF (BB_UB6, BB_K9 and BB_K2), B3: 4 isolates BPF (BB_UB6, BB_K9, $B B_{-} K 2$, and $B B_{-} H_{S 13)}$. The results showed soil sterilization decrease the number of primary branch becomes 5.67 and $1.49 \mathrm{~g}$ dry weight of the plant. The fastest time of harvest occurs in plants without inoculation of sterile soil that is 78.78 . The highest weight of 100 seeds produced by the plant without inoculation of sterile soil that is $13.17 \mathrm{~g}$.
\end{abstract}

Keywords : phosphate, solubilizing, bacteria, soybean, growth, yield

\section{PENDAHULUAN}

Fosfor adalah salah satu unsur hara esensial makro yang berperan sangat penting dalam pertumbuhan dan perkembangan tanaman. Keberadaanya di tanah melimpah namun konsentrasi $P$ yang dapat diserap oleh tanaman justru sangat rendah. Konsentrasi $P$ tersedia dalam tanah dipengaruhi oleh $\mathrm{pH}$ dan jenis tanah. Pada tanah masam $P$ terikat dengan Aluminium (Al) dan besi $(\mathrm{Fe})$, sedangkan di tanah alkalin $\mathrm{P}$ terikat dengan Kalsium (Ca). Adanya pengikatan-pengikatan $P$ tersebut menyebabkan pupuk $P$ yang diberikan menjadi tidak efisien, karena bahkan sesaat setelah diberikan akan terjadi imobilisasi $P$ hingga menjadi tidak tersedia bagi tanaman.

Peningkatan efisiensi ketersediaan fosfat bagi tanaman dapat diupayakan dengan cara memanfaatkan kelompok mikroorganisme pelarut fosfat. Bakteri pelarut fosfat (BPF) merupakan kelompok bakteri yang dapat melarutkan $P$ yang terjerap permukaan oksidaoksida besi dan almunium sebagai senyawa Fe-P dan Al-P (Hartono, 2000). Efek pelarutan disebabkan oleh adanya produksi asam organik seperti asam asetat, asam format, asam laktat, asam oksalat, asam malat dan asam sitrat yang dihasilkan oleh mikroba tersebut (Narsian dan Patel 2000). BPF juga melarutkan $\mathrm{P}$ dengan mekanisme pengeluaran enzim. Enzim tanah yang berperan dalam proses mineralisasi senyawa $P$ organik menjadi $P$ anorganik adalah kelompok enzim yang dikenal dengan nama fosfatase (Sarapatka, 2002). Fosfatase di tanah dapat berasal dari akar tanaman dan mikroorganisme, akan tetapi jumlah yang lebih dominan adalah fosfatase yang dihasilkan oleh mikroorganisme (Joner dan Johansen, 2000). 
Uji potensi kelarutan P oleh BPF yang diisolasi dari tanah gambut Cagar Biosfer Giam Siak Kecil Bukit Batu, Riau telah dilakukan dan diketahui secara semi kuantitatif mampu melarutkan $\mathrm{Ca}_{3}\left(\mathrm{PO}_{4}\right)_{2}, \mathrm{FePO}_{4}$ dan batuan fosfat. Kemampuan adaptasi dan potensi pelarutan BPF asal tanah gambut indigenus Riau yang diinokulasikan pada tanaman kedelai di tanah mineral sampai saat ini belum diketahui. Penelitian ini dilaksanakan dengan tujuan untuk mengetahui pengaruh inokulasi BPF indigenus Riau terhadap pertumbuhan dan produksi tanaman kedelai.

\section{BAHAN DAN METODE}

Penelitian dilakukan secara
eksperimen faktorial menggunakan Rancangan Acak Lengkap (RAL Faktorial), sebagai faktor 1 adalah perlakuan tanah yang terdiri dari 2 taraf yaitu: $\mathrm{T}_{0}$ : tanah tanpa sterilisasi, $T_{1}$ : tanah disterilisasi, Faktor kedua yaitu pemberian isolat BPF yang terdiri dari 4 taraf yaitu: $B_{0}$ : tanpa inokulasi BPF $B_{1}: 2$ isolat BPF (BB_UB6 dan BB_K9), $B_{2}: 3$ isolat BPF (BB_UB6, BB_K9 dan BB_K2), B 3 : 4 isolat BPF (BB_UB6, BB_K9, BB_K2, dan BB_HS13). Data yang diperoleh dianalisis secara statistik dengan Analisis Of Variance (ANOVA) menggunakan program SAS 9.1. Hasil sidik ragam diuji dengan Duncan pada taraf $5 \%$.

\section{Pembuatan Starter BPF}

Starter 1 (campuran dari 2 isolat BPF) : Pembuatan starter 1 diawali dengan pembuatan starter dari dua isolat (BB_UB6 dan BB_K9 ) dengan cara menginokulasikan 1 ose masing-masing isolat bakteri ke dalam 10 $\mathrm{ml}$ medium Pikovskaya cair dan dilanjutkan inkubasi pada suhu ruang selama 24 jam dengan agitasi $150 \mathrm{rpm}$. Setelah masa inkubasi, $10 \mathrm{ml}$ dari setiap inokulum BPF tersebut diinokulasikan ke dalam Erlenmeyer yang berisi $40 \mathrm{ml}$ medium Pikovskaya cair. Kultur selanjutnya diinkubasi selama 24 jam pada suhu ruang dengan agitasi $150 \mathrm{rpm}$. Setelah masa inkubasi masing-masing inokulum dicampur jadi satu sehingga menghasilkan inokulum 1 dengan volume 100 $\mathrm{ml}$ yang terdiri atas campuran 2 isolat dengan rasio 1:1.

Starter 2 (campuran 3 isolat BPF): Pembuatan starter 2 diawali dengan pembuatan starter dari tiga isolat (BB_UB6, BB_K9, dan BB_K2) dengan cara menginokulasikan 1 ose masing-masing isolat bakteri ke dalam $10 \mathrm{ml}$ medium Pikovskaya cair dan dilanjutkan inkubasi pada suhu ruang selama 24 jam dengan agitasi $150 \mathrm{rpm}$.
Setelah masa inkubasi, $5 \mathrm{ml}$ dari setiap inokulum BPF tersebut diinokulasikan ke dalam Erlenmeyer yang berisi $45 \mathrm{ml}$ medium Pikovskaya cair. Kultur selanjutnya diinkubasi selama 24 jam pada suhu ruang dengan agitasi $150 \mathrm{rpm}$. Setelah masa inkubasi masing-masing inokulum dicampur jadi satu sehingga menghasilkan starter 2 dengan volume $120 \mathrm{ml}$ yang terdiri atas campuran 3 isolat dengan rasio 1:1:1.

Starter 3 (campuran dari 4 isolat BPF): Pembuatan starter 3 diawali dengan pembuatan starter dari empat isolat (BB_UB6, BB_K9, BB_K2, dan BB_HS13) dengan cara menginokulasikan 1 ose masing-masing isolat bakteri ke dalam $5 \mathrm{ml}$ medium Pikovskaya cair dan dilanjutkan inkubasi pada suhu ruang selama 24 jam dengan agitasi $150 \mathrm{rpm}$. Setelah masa inkubasi, $5 \mathrm{ml}$ dari setiap inokulum BPF tersebut diinokulasikan ke dalam Erlenmeyer yang berisi $20 \mathrm{ml}$ medium Pikovskaya cair. Kultur selanjutnya diinkubasi selama 24 jam pada suhu ruang dengan agitasi $150 \mathrm{rpm}$. Setelah masa inkubasi masing-masing inokulum dicampur jadi satu sehingga menghasilkan starter 1 dengan volume $100 \mathrm{ml}$ yang terdiri atas campuran 4 isolat dengan rasio 1:1:1:1.

\section{Persiapan media tanam}

Top soil tanah dicangkul sedalam kurang lebih $30 \mathrm{~cm}$ lalu dikumpulkan. Tanah yang telah terkumpul lalu dihaluskan menggunakan sekop dan diayak. Tanah tanpa sterilisasi dimasukkan ke dalam polibek sebanyak $5 \mathrm{~kg} /$ polibek. Sterilisasi tanah dilakukan dengan metode tyndalisasi, yaitu tanah secara bertahap diuapkan (dikukus) pada suhu $100^{\circ} \mathrm{C}$ selama 1 jam, diulang tiga kali berturut-turut dengan selang waktu 24 jam. Tanah yang telah disterilisasi dan tanpa sterilisasi kemudian dibiarkan selama kurang lebih 1 hari, setelah itu ditambahkan batuan fosfat dengan dosis $0,75 \mathrm{~g} /$ polibek dan pupuk kandang yang telah disterilisasi sebanyak 25 $\mathrm{gr} /$ polibek. Setelah dibiarkan kembali selama 1 minggu, media siap untuk ditanami.

\section{Sterilisasi permukaan benih, pra perkecambahan dan inokulasi}

Permukaan benih disterilisasi dengan mengikuti metode sterilisasi Hallmann et al., 1997. Benih kedelai dicuci, lalu direndam dalam alkohol $70 \%$ selama 1 menit. Kemudian direndam kembali dalam $\mathrm{NaOCl} 2,5 \%$ selama 8 menit lalu dibilas dengan air steril sebanyak 3 kali.Benih yang telah disterilisasi permukaan kemudian di pra kecambahkan dengan cara meletakkan benih pada tumpukan kapas basah hingga kulit biji pecah dan 
berkecambah. Benih yang telah berkecambah kemudian direndam dengan starter BPF sesuai perlakuan selama 2 jam, setelah itu benih siap ditanam.

\section{Penanaman dan pemeliharaan}

Penanaman benih kedelai dilakukan pada media tanam yang sudah dipersiapkan sebelumnya dengan cara membuat lubang dengan kedalaman $3 \mathrm{~cm}$ pada media tanam. Kemudian tiap lubang yang telah dibuat diisi dengan 2 biji tanaman kedelai. Setelah benih tumbuh, dilakukan penjarangan pada setiap polibek dengan jarak $40 \mathrm{~cm} \times 40$. Pemberian pupuk tambahan yakni pupuk urea dengan dosis 0,125 gram/polibek dan $\mathrm{KCl} 0,5$ gr/polibek dilakukan pada 20-30 hari setelah tanam.Pengamatan yang diamati meliputi tinggi tanaman, jumlah cabang primer, jumlah cabang produktif, berat kering tanaman, umur panen, jumlah dan persentase polong bernas, jumlah biji per tanaman, bobot biji per tanaman dan bobot 100 biji.

\section{HASIL DAN PEMBAHASAN}

\section{Sifat Kimia Tanah Awal}

Sifat kimia tanah alluvial yang digunakan untuk penelitian disajikan pada Tabel 1. Tanah yang digunakan bereaksi masam. $\mathrm{pH} \mathrm{KCl}$ lebih rendah dari $\mathrm{pH} \mathrm{H}_{2} \mathrm{O}$ menunjukkan koloid tanah didominasi oleh koloid bermuatan yang tergantung $\mathrm{pH}$ (variable charge).

Pada pH tinggi koloid bermuatan negatif akan lebih tinggi, sedangkan pada $\mathrm{pH}$ rendah muatan negatif koloid ikut rendah. Sumber koloid tergantung $\mathrm{pH}$ tersebut terutama bersumber dari koloid organik. Hal ini ditunjukkan oleh tingginya kandungan Corganik tanah yaitu $4,70 \%$ dan nisbah $\mathrm{C} / \mathrm{N}<$ 20.

Tingginya kandungan C-organik dan nisbah $\mathrm{C} / \mathrm{N}$ menunjukkan bahan organik telah mengalami dekomposisi menghasilkan koloidkoloid organik. Nisbah $\mathrm{C} / \mathrm{N}$ tanah $<20$ mengindikasikan proses mineralisasi berlangsung lebih besar dari pada imobilisasi.

P-tersedia pada tanah awal tergolong sangat rendah, hal ini menunjukkan bahwa tanah dalam kondisi miskin $\mathrm{P}$. Jenis tanah yang digunakan dalam penelitian ini adalah alluvial, yang berada di daerah aliran sungai Batang Lubuh Rokan Hulu.

Sebagian besar tanah alluvial di Riau adalah endapan dari aliran sungai dan tanah ultisol di daerah hulu. Kondisi tanah ini miskin $\mathrm{P}$ namun kaya $\mathrm{K}$, $\mathrm{Ca}$ dan $\mathrm{Mg}$.
Tabel 1. Sifat kimia tanah alluvial yang digunakan untuk penelitian

\begin{tabular}{lccc}
\hline $\begin{array}{c}\text { Sifat Kimia } \\
\text { Tanah }\end{array}$ & Satuan & Nilai & Kriteria \\
\hline $\mathrm{pH} \mathrm{H} \mathrm{H}_{2} \mathrm{O}$ & & 5,41 & Masam \\
$\mathrm{PH} \mathrm{KCl}$ & & 4,54 & Masam \\
C-Organik & $\%$ & 4,70 & Tinggi \\
$\mathrm{N}$ Total & $\%$ & 0,26 & Sedang \\
$\mathrm{C} / \mathrm{N}$ & & 18,08 & Tinggi \\
$\mathrm{P}_{2} \mathrm{O}_{5}$ (Bray 1) & $\mathrm{Ppm}$ & 4,79 & Rendah \\
$\mathrm{K}$ tersedia & $\mathrm{mg} / 100 \mathrm{~g}$ & 20,62 & Tinggi \\
$\mathrm{Ca}-\mathrm{dd}$ & $\mathrm{me} / 100 \mathrm{~g}$ & 13,25 & Tinggi \\
$\mathrm{K}-$ dd & $\mathrm{me} / 100 \mathrm{~g}$ & 0,93 & Tinggi \\
$\mathrm{Mg}-$ dd & $\mathrm{me} / 100 \mathrm{~g}$ & 4,85 & Sedang \\
$\mathrm{Na}-\mathrm{ddd}$ & $\mathrm{me} / 100 \mathrm{~g}$ & 0,17 & Rendah \\
$\mathrm{KTK}$ & $\mathrm{me} / 100 \mathrm{~g}$ & 57,03 & Sangat tinggi \\
$\mathrm{KB}$ & $\%$ & 33,66 & Rendah \\
Kejenuhan Al & $\%$ & 0,22 & Sangat \\
\hline
\end{tabular}

\section{Parameter Pertumbuhan Tanaman}

Pengaruh utama sterilisasi tanah, inokulasi starter BPF dan interaksi keduanya tidak meningkatkan tinggi tanaman kedelai (Tabel 2). Hal ini mengindikasikan bahwa inokulasi BPF dan sterilisasi tanah tidak mampu menstimulasi tersedianya hara $P$ yang optimal untuk pertambahan tinggi tanaman kedelai. Prastyowati (2008) melaporkan dalam penelitiannya bahwa inokulasi BPF pada kedelai berpengaruh tidak nyata terhadap tinggi tanaman yang diukur pada $30 \mathrm{HST}$. Birnadi (2012) juga menyatakan penambahan BPF pada kedelai tidak nyata mempengaruhi tinggi tanaman. Pemupukan $\mathrm{P}$ juga diketahui tidak berpengaruh nyata terhadap tinggi tanaman kedelai (Rukmi, 2009). Namun Schoebitz et al. (2013) melaporkan adanya peningkatan tinggi tanaman gandum akibat inokulasi BPF.

Jumlah cabang primer tanaman kedelai meningkat secara nyata pada medium tanah nonsteril dibandingkan pada medium tanah steril, akan tetapi inokulasi BPF tidak meningkatkan jumlah cabang primer tanaman kedelai (Tabel 2). Interaksi antara inokulasi BPF dengan tanah nonsteril maupun steril juga tidak mempengaruhi jumlah cabang primer tanaman kedelai, namun terdapat kecenderungan inokulasi starter 1 pada tanah nonsteril meningkat 2 kali lipat dibanding pada tanah steril.

Tabel 2 menunjukkan inokulasi BPF dan sterilisasi tanah tidak meningkatkan jumlah cabang produktif. Hal ini menunjukkan bahwa dengan ataupun tanpa inokulasi BPF dan sterilisasi tanah, tidak mempengaruhi jumlah cabang produktif pada tanaman kedelai. Akan tetapi terdapat kecenderungan jumlah cabang produktif meningkat bila dibandingkan dengan kontrol. Inokulasi starter 2 menghasilkan jumlah cabang produktif 
tanaman kedelai paling banyak dibandingkan dengan starter lainnya. Sementara itu jumlah cabang produktif tanaman kedelai pada medium tanah nonsteril cenderung lebih banyak dibandingkan pada medium tanah steril.

Tabel 2. Tinggi tanaman, jumlah cabang primer, jumlah cabang produktif dan berat kering tanaman kedelai dengan inokulasi 3 campuran isolat BPF pada tanah steril dan nonsteril

\begin{tabular}{|c|c|c|c|c|c|c|}
\hline \multirow{4}{*}{ Tinggi Tanaman } & Tanah & Tanpa BPF & Starter 1 & Starter 2 & Starter 3 & Rata-rata \\
\hline & Non steril & $51,73^{a}$ & $58,67^{a}$ & $52,83^{a}$ & $59,80^{a}$ & $55,76^{a}$ \\
\hline & Steril & $58,80^{a}$ & $43,80^{a}$ & $57,90^{a}$ & $45,97^{a}$ & $51,62^{a}$ \\
\hline & Rata-rata & $55,27^{a}$ & $51,23^{a}$ & $55,37^{a}$ & $52,88^{a}$ & \\
\hline \multirow{3}{*}{ Jumlah Cabang Primer } & Non Steril & $8,33^{a}$ & $10,67^{a}$ & $6,00^{a}$ & $8,00^{a}$ & $8,25^{a}$ \\
\hline & Steril & 5,67 a & $5,67^{a}$ & $5,33^{a}$ & $6,00^{a}$ & $5,67^{b}$ \\
\hline & Rata-rata & $7,00^{a}$ & $8,17^{a}$ & $5,67^{a}$ & $7,00^{a}$ & \\
\hline \multirow{3}{*}{$\begin{array}{c}\text { Jumlah cabang } \\
\text { Produktif }\end{array}$} & Non Steril & $14,44^{\mathrm{a}}$ & $15,22^{a}$ & $13,11^{a}$ & $18,22^{a}$ & $15,25^{a}$ \\
\hline & Steril & $10,56^{\mathrm{a}}$ & $11,22^{a}$ & $19,33^{a}$ & $12,67^{a}$ & $13,44^{a}$ \\
\hline & Rata-rata & $12,50^{a}$ & $13,22^{a}$ & $16,22^{a}$ & $15,44^{a}$ & \\
\hline \multirow{3}{*}{ Berat kering tanaman } & Non steril & $4,53^{a}$ & $3,51^{\mathrm{a}}$ & $1,81^{\mathrm{a}}$ & $5,45^{a}$ & $3,83^{a}$ \\
\hline & Steril & $1,28^{a}$ & $1,71^{\mathrm{a}}$ & $1,82^{a}$ & $1,16^{\mathrm{a}}$ & $1,49 \mathrm{~b}$ \\
\hline & Rata-rata & $2,90^{a}$ & $2,61^{a}$ & $1,82^{a}$ & $3,31^{a}$ & \\
\hline
\end{tabular}

Ket: Angka yang diikuti huruf kecil yang sama pada baris atau kolom yang sama, berbeda tidak nyata menurut uji jarak berganda Duncan $5 \%$

Cabang produktif mempengaruhi jumlah polong yang dihasilkan pada tanaman. Semakin banyak jumlah cabang produktif maka semakin banyak pula jumlah polong yang dihasilkan. Inokulasi BPF dan sterilisasi tanah tidak nyata mempengaruhi jumlah cabang produktif diduga karena serapan $P$ tanaman tidak cukup signifikan dalam meningkatkan jumlah cabang produktif. Akan tetapi Samuli et al. (2012) menyatakan bahwa jumlah cabang produktif dapat meningkat akibat penambahan bokashi kotoran sapi. Hal ini menunjukkan bahwa jumlah cabang primer tanaman kedelai dapat meningkat akibat adanya penambahan bahan organik sehingga memperbaiki kondisi tanah dan meningkatkan kehidupan biologi tanah, yang berakibat pada optimalisasi ketersediaan dan keseimbangan daur hara.

Berat kering tanaman kedelai mengalami peningkatan pada tanah non steril dibandingkan pada tanah steril (Tabel 2). Berat kering tanaman kedelai pada tanah non steril mengalami peningkatan dua kali lebih tinggi dibandingkan pada tanah steril. Pengaruh utama inokulasi starter BPF tidak meningkatkan berat kering tanaman kedelai. Akan tetapi, terdapat kecenderungan inokulasi starter 3 menghasilkan berat kering tanaman yang lebih tinggi dibanding kontrol, starter 1 dan 2. Hal ini menunjukkan bahwa perlakuan tanpa sterilisasi tanah mampu meningkatkan pertumbuhan tanaman yang ditandai dengan meningkatkan biomassa tajuk dan akar. Peningkatan ini diduga disebabkan karena adanya mikroba indigenus tanah yang turut serta dalam penyediaan unsur hara di tanah dan memperbaiki sifat biologi tanah. Cahyani (2009) menyatakan bahwa perlakuan sterilisasi tanah diketahui sangat nyata mempengaruhi status hara tanah, populasi dan aktifitas mikrobiota, pembentukan nodul dan pertumbuhan tanaman kedelai.

Berat kering tanaman menunjukkan banyaknya unsur hara yang terserap per satuan bobot biomassa yang dihasilkan. Tingginya berat kering tanaman yang dihasilkan mengindikasikan banyaknya unsur hara yang dapat diserap oleh tanaman sehingga pertumbuhan tanaman semakin baik. Cahyani (2009) melaporkan bahwa berat kering tanaman kedelai pada tanah non steril dengan inokulasi mikoriza juga lebih tinggi dibanding pada tanah yang disterilisasi. Wangiyana et al. (2011) menyatakan bahwa tanaman kedelai varietas Wilis lebih peka terhadap sterilisasi tanah dan menghasilkan berat kering yang lebih rendah dibanding varietas lainnya. Akan tetapi, inokulasi BPF menunjukkan hasil yang signifikan terhadap berat kering tanaman cabe rawit (Permatasari dan Nurhidayati, 2014) dan jagung (Tamad et al., 2013)

\section{Parameter Produksi Tanaman}

Inokulasi BPF dan sterilisasi tanah tidak mempengaruhi umur panen tanaman kedelai (Tabel 3). Akan tetapi interaksi antar kedua perlakuan mampu mempercepat umur panen tanaman kedelai. Umur panen tercepat adalah tanaman dengan kombinasi perlakuan tanpa BPF pada tanah yang disterilkan yakni 78,78 hari, sedangkan umur panen terlama adalah pada perlakuan tanah steril yang diinokulasi starter 2 yakni 89,78 hari. Umur panen yang lebih cepat diduga disebabkan karena pada medium tanah steril dan tanpa inokulasi BPF mikroorganisme yang 
terkandung lebih sedikit, sehingga membatasi pemenuhan kebutuhan unsur hara. Tanaman yang berada pada kondisi tercekam akan beradaptasi dengan cara mempercepat proses pemasakan biji dan polong, sehingga umur panen dapat menjadi lebih cepat. Sumardi (2014) menyatakan umur panen tanaman kedelai tergantung varietas dan faktor genetik dari tanaman tersebut. Umur panen tanaman menjadi panjang atau pendek juga disebabkan oleh beberapa faktor lingkungan, seperti cahaya matahari, curah hujan, kelembaban dan cuaca.

Tabel 3. Tinggi tanaman, jumlah cabang primer, umur panen, bobot biji per tanaman, bobot 100 biji

\begin{tabular}{|c|c|c|c|c|c|c|}
\hline \multirow{3}{*}{ Umur Panen } & Non Steril & $82,11^{a b}$ & $81,11^{b}$ & $81,89 a b$ & $86,89 a b$ & $83,00^{a}$ \\
\hline & Steril & $78,78^{b}$ & $84,56^{a b}$ & $89,78^{a}$ & $80,11^{b}$ & $83,31^{a}$ \\
\hline & Rata-rata & $80,45^{a}$ & $82,83^{a}$ & $85,84^{a}$ & $83,50^{a}$ & \\
\hline \multirow{3}{*}{ Bobot Biji Per Tanaman } & Non steril & $4,33^{a}$ & $4,11^{a}$ & $3,43^{a}$ & $3,37^{a}$ & 3,81 a \\
\hline & Steril & $5,13^{a}$ & $2,00^{a}$ & 0,59 a & $3,18^{a}$ & 2,73 a \\
\hline & Rata-rata & $4,73^{a}$ & $3,06^{a}$ & $2,01^{a}$ & $3,28^{a}$ & \\
\hline \multirow{3}{*}{ Bobot 100 biji } & Non steril & $13,20^{a}$ & $12,40^{b}$ & $11,10^{c}$ & $12,87^{a b}$ & $12,39^{a}$ \\
\hline & Steril & $13,13 \mathrm{ab}$ & $12,80 \mathrm{ab}$ & $12,54 \mathrm{ab}$ & $11,67^{c}$ & $12,54^{a}$ \\
\hline & Rata-rata & $13,17^{a}$ & $12,60^{b}$ & $11,82^{b c}$ & $12,27^{c}$ & \\
\hline
\end{tabular}

Ket: Angka yang diikuti huruf kecil yang sama pada baris atau kolom yang sama, berbeda tidak nyata menurut uji jarak berganda Duncan $5 \%$

Tabel 3 menunjukkan bahwa inokulasi campuran BPF dan sterilisasi tanah tidak meningkatkan bobot biji per tanaman. Akan tetapi terdapat kecenderungan bobot biji pada tanaman tanpa inokulasi lebih tinggi dibandingkan dengan inokulasi 3 jenis starter BPF. Sedangkan tanaman dengan medium tanah nonsteril menghasilkan bobot biji tanaman yang cenderung lebih tinggi dibandingkan dengan tanah steril. Inokulasi starter BPF dan interaksi antar perlakuan berpengaruh negatif terhadap bobot 100 biji kedelai. Tanaman yang tidak diinokulasi justru menghasilkan bobot 100 biji yang lebih besar dibandingkan dengan tanaman dengan inokulasi BPF. Tanaman kontrol menghasilkan bobot 100 biji tertinggi yakni $13,17 \mathrm{~g}$. Hasil ini lebih tinggi dari deskripsi umum tanaman kedelai varietas Wilis yang memiliki bobot 100 biji pada kisaran 10 g. Hal ini mengisyarakatkan bahwa inokulasi BPF mampu meningkatkan aktifitas fosfatase namun tidak memberikan pengaruh nyata terhadap produksi tanaman kedelai.

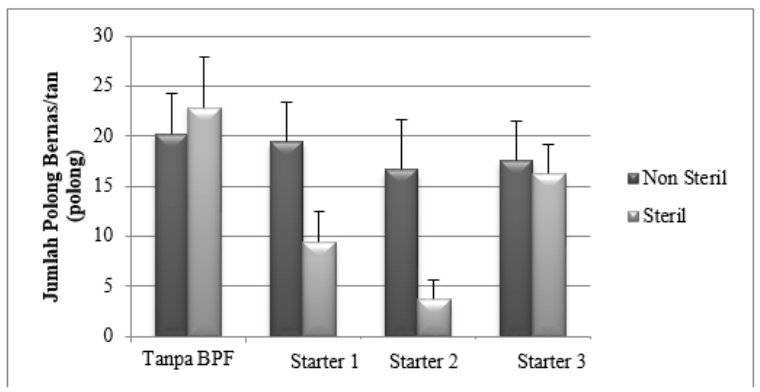

Gambar 1. Jumlah polong bernas per tanaman
Inokulasi BPF dan sterilisasi tanah tidak meningkatkan jumlah (Gambar 1) dan persentase polong bernas (Gambar 2) per tanaman. Akan tetapi terdapat kecenderungan jumlah dan persentase polong bernas tertinggi diperoleh pada tanaman tanpa inokulasi BPF pada tanah non steril. Sedangkan pada perlakuan dengan inokulasi starter BPF, jumlah dan persentase polong bernas cenderung lebih tinggi pada tanah non steril dibanding pada tanah steril.

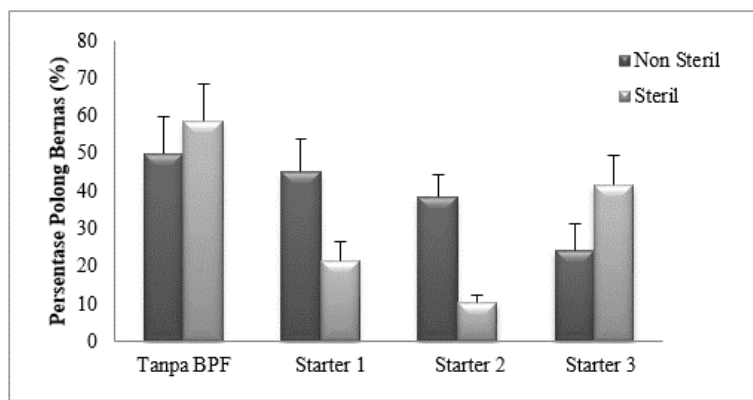

Gambar 2. Persentase polong bernas per tanaman

Secara umum jumlah dan persentase polong bernas per tanaman sangat rendah, yakni dalam kisaran 3,67 sampai 22,69 dengan persentase $10,36 \%$ hingga $58,71 \%$. Hasil ini lebih rendah dari Samuli et al. (2012), dimana jumlah polong tanaman kedelai yang dihasilkan dari penambahan bokashi kotoran sapi mencapai 73,79. Hal ini disebabkan karena kondisi lingkungan di Rokan Hulu pada saat penelitian berlangsung sedang terkena bencana asap yang sangat parah, sehingga mempengaruhi intensitas cahaya matahari dan mempengaruhi laju fotosintesis pada tanaman. Kondisi ini diperparah dengan tingginya serangan penyakit pada masa pengisian polong sehingga mempengaruhi jumlah dan 
persentase polong bernas per tanaman. Unsur $\mathrm{P}$ pada tanaman diketahui memiliki peran dalam pengisian biji dan polong. Penelitian sebelumnya tentang inokulasi BPF menunjukkan adanya pengaruh nyata inokulasi BPF terhadap jumlah polong. Seperti yang dilaporkan oleh Widawati et al. (2015) yang menyatakan bahwa Plant Grow Promoting Rhizobacteria (PGPR) dimana di dalamnya terdapat bakteri pelarut fosfat terbukti efektif meningkatkan jumlah polong pada tanaman kedelai dibanding tanpa inokulasi. Hal yang sama juga dilaporkan oleh Silitonga et al. (2013) bahwa isolat BPF memiliki potensi untuk meningkatkan jumlah polong tanaman kedelai pada tanah kuning.

\section{KESIMPULAN DAN SARAN}

\section{Kesimpulan}

Berdasarkan hasil penelitian dapat disimpulkan bahwa sterilisasi tanah mampu meningkatkan jumlah cabang primer dan berat kering tanaman, namun sebaliknya inokulasi BPF belum mempengaruhi parameter pertumbuhan. Sterilisasi tanah juga mempengaruhi umur panen dan bobot 100 biji kedelai. Akan tetapi secara keseluruhan inokulasi BPF belum mampu meningkatkan produksi kedelai.

\section{Ucapan Terima Kasih}

Ucapan terima kasih disampaikan kepada Ibu Delita Zul dan Ibu Nelvia yang telah membimbing penulis dalam melakukan penelitian ini.

\section{DAFTAR PUSTAKA}

Birnadi, S. 2012. Respons tanaman padi organik (Oryza sativa L.) terhadap bakteri pelarut fosfat (BPF) dan Mikoriza Vesikular Arbuskular (MVA). Jurnal Istek 7(1-2):

Cahyani, Vita Ratri. 2009. Pengaruh beberapa metode sterilisasi tanah terhadap status hara, populasi mikrobiota, potensi infeksi mikoriza dan pertumbuhan tanaman. Sains tanah - Jurnal IImiah IImu Tanah Dan Agroklimatologi 6(1)

Hallmann J, Quadt-Hallmann A, Mahaffee WF, Kloepper JW. 1997. Bacterial endophytes in agricultural crops. Journal Microbiology. 43(10):895-914. doi: 10.1139/m97-131

Hartono, A. 2000. Pengaruh pupuk fosfor, bahan organik dan kapur terhadap pertumbuhan jerapan $\mathrm{P}$ pada tanah masam latosol Darmaga. Gakuryoku 6 (1): 73-78

Joner, E..J. \& A. Johansen (2000). Phosphatase activity of external hyphae of two arbuscular mycorrhizal fungi. Mycol. Res., 104, 12-16.

Narsian, V. dan H.H. Patel. 2000. Aspergillus Aculeatus As A Rock Phosphate Solubilizer. Soil Biology. Biochemistry, 32, 559-565

Permatasari, A.D dan Nurhidayati, T. 2014. Pengaruh inokulan bakteri penambat nitrogen, bakteri pelarut fosfat dan mikoriza asal Desa Condro, Lumajang, Jawa Timur terhadap pertumbuhan tanaman cabe rawit. Jurnal Sains dan Seni 3(2)

Prastyowati, Novi. 2008. Pengujian Kompabilitas antara Mikroba Pelarut Fosfat Asal Tanah Paku Haji Tangerang dengan Tanaman Kedelai (Glycine mz. L.Merr) Varietas Wilis. Skripsi. Program Studi Biologi. Fakultas IImu Sains dan Teknologi. Universitas Islam Negeri Syarif Hidayatullah. Jakarta.

Rukmi. 2009. Pengaruh Pemupukan Kalium dan Fosfat terhadap Pertumbuhan dan Hasil Kedelai. Fakultas Pertanian UMK. www.eprint.umk.ac.id diunduh tanggal 12 Maret 2016.

Saparatka, B. 2002. Phosphatase activity of eutric cambisols (Upland, Sweeden) in relation to soil properties and farming systems. Journal Acta Agriculturae Bohemica, 33 (1): 18-24

Samuli, LO., Karimuna, L., Sabaruddin, L. 2012. Produksi kedelai (Glycine max L. Merrill) pada berbagai dosis bokashi kotoran sapi. Jurnal berkala Agronomi. 1(2):145-147

Schoebitz, M., Ceballos, C and Ciampi, L. 2013. Effect of Immobilized phosphate solubilizing bacteria on wheat growth and phosphate uptake. Journal of Soil Science and Plant Nutrition 13(1):1-10

Silitonga, DM., Priyan, N., Nurwahyuni, I. 2013. Isolasi dan uji potensi isolat bakteri pelarut fosfat dan bakteri penghasil hormon iaa (Indole Acetic Acid) terhadap pertumbuhan kedelai (Glycine max L.) pada tanah kuning. Jurnal Portal Garuda. Hal 35-41

Sumardi. 2014. Pertumbuhan dan Hasil Beberapa Varietas Kedelai (Glycine Max L.) Terhadap Jenis Pupuk Pelengkap Cair. Skripsi. Program Studi Agroteknologi. Fakultas Pertanian Universitas Tamansiswa. Padang

Tamad., Ma'as. A., Radjagukguk. B., Hanudin. E., Widada. J. 2013. Ketersediaan fosfor 
Jurnal Agroteknologi, Vol. 7 No. 1, Agustus $2016: 7$ - 14

pada tanah andisol untuk jagung (Zea mays L.) oleh inokulum bakteri pelarut fosfat. Jurnal Agron. Indonesia 41(2): 112-117

Widawati, Sri., Suliasih., Saefudin. 2015. Isolasi dan Uji Efektifitas Plant Growth Promoting Rhizobacteria di Lahan Marginal pada Pertumbuhan Tanaman Kedelai (Glycine max L. Merr.) varietas Wilis. Prosiding Seminar Nasional
Masyarakat Biodiversitas Indonesia. 1(1): 59-65

Wangiyana, Wayan., Ari Apriani dan Nihla Farida. 2011. respon berbagai varietas kedelai (Glycine Max (L.) Merril) terhadap sterilisasi tanah dan inokulasi dengan mikoriza arbuskular. Agrotekso, 21(1). 
Pengaruh Inokulasi Campuran Isolat Bakteri Pelarut Fosfat (Lufita Nur Alfiah, et al.) 


\section{$\mathbf{J}$

PEMBERIAN KOMPOS TKKS DAN COCOPEAT PADA TANAH SUBSOIL ULTISOL TERHADAP PERTUMBUHAN BIBIT KELAPA SAWIT (Elaeis guineensis Jacq.) DI PRE NURSERY

Composting EFB And Cocopeat On Subsoil Ultisol To The Growth Of Palm Oil Seedlingsin Pre Nursery

Siziko Andri, Nelvia, Sukemi Indra Saputra

PENGARUH INOKULASI CAMPURAN ISOLAT BAKTERI PELARUT FOSFAT INDIGENUS RIAU TERHADAP PERTUMBUHAN DAN PRODUKSI TANAMAN KEDELAI (Glycine max L. Merr)

Effect of Riau Indigenus Phosphate Solubilizing Bacteria Isolate Mixture Inoculation on Soybean Growth and Yield

Lufita Nur Alfiah, Delita Zul, Nelvia

PROPAGASI IN VITRO ANGGREK (Dendrobium phalaenopsis Fitzg) TERHADAP PEMBERIAN HORMON IBA DAN KINETIN

In Vitro Propagation of Orchid (Dendrobium phalaenopsis Fitzg) on The Addition Iba and Kinetion Hormones

Imam Mahadi

PEMBERIAN BEBERAPA AMELIORAN TERHADAP PERUBAHAN SIFAT KIMIA TANAH GAMBUT

Giving Some Ameliorants To Changes Chemical Properties of Peat Soil

Ervina Aryanti, Yulita, Aulia Rani Annisava

ANALISIS PEMASARAN PADI SAWAH DI KECAMATAN RAMBAH SAMO KABUPATEN ROKAN HULU

Marketing Analysis Of Paddy Field In The Rambah Samo District Rokan Hulu Regency

Darus

KEANEKARAGAMAN SERANGGA PADA TUMPANGSARI TANAMAN PANGAN SEBAGAI TANAMAN SELA DI PERTANAMAN KELAPA SAWIT BELUM MENGHASILKAN Insect Diversity on Intercropping System in Young Palm Oil

Lutfi Arifin, Mokhammad Irfan, Indah Permanasari, Auli Rani Annisava, dan A. Taufiq Arminudin ....... 